\title{
Potential Incentive for Green Product: Imposing Excise on Hybrid Car in Indonesia
}

\author{
Noor Syaifudin \\ Ministry of Finance of Republic of Indonesia, Indonesia \\ soib2000@yahoo.com
}

\begin{abstract}
By 2012, the Government committed to provide incentive for hybrid car which able to consume 1 liter gasoline for $30 \mathrm{~km}$ trip. The incentive will be applied on two steps; the first step is on the import of completed built up (CBU) hybrid car and the second pace is on the assembling (manufacturing) of the hybrid car. Thus, this paper aims to study the possibility of providing incentive to hybrid car by imposing excise. The study will be mainly discussing the existing regulations on taxation on hybrid car and excise imposition in Indonesia, how the literature talks about excise, and how the incentive could be applied for hybrid car particularly. The data was collected from literature study, best practices, regulations review, focus group discussions and in-depth interview. The study found that excise has several merit to provide incentive for green product and hybrid car particularly. In order to minimize the potential extra taxation, the government may switch the Luxury Goods Tax (LGT) to excise. The incentive itself can be applied with discriminations on tariff with several purposes.
\end{abstract}

Keywords: Excise, fiscal policy, RAN GRK

\section{Introduction}

President commitment: The Presidential Decree No. 61 Year 2011 on the National Action Plan for Greenhouse Gas Emission reduction has been seen as a strong commitment of government to reduce and control the greenhouse gas. The Plan was stipulated as the follow up of the commitment of the Government of Indonesia in the G-20 meeting in Pittsburgh to reduce greenhouse gas emissions by 26 percent voluntarily and reach 41 percent with international assistance.

Table 1: The Emission Reduction Target based on Sectors

\begin{tabular}{|c|c|c|c|c|}
\hline \multirow[t]{2}{*}{ Sectors } & \multicolumn{2}{|c|}{$\begin{array}{l}\text { Emission Reduction Target } \\
\text { (Giga Ton Co2e) }\end{array}$} & \multirow[t]{2}{*}{ Action Plan } & \multirow[t]{2}{*}{ Executing Agency } \\
\hline & $26 \%$ & $\begin{array}{l}15 \% \quad \text { (of } \\
\text { Total } 41 \%)\end{array}$ & & \\
\hline $\begin{array}{l}\text { Forestry and } \\
\text { Peat land }\end{array}$ & 0.672 & 0.367 & $\begin{array}{l}\text { Forest fire control, water control and } \\
\text { management, forest and land } \\
\text { rehabilitation, industrial plant forest, } \\
\text { reforestation, illegal logging control, } \\
\text { reduce deforestation, community } \\
\text { development }\end{array}$ & $\begin{array}{l}\text { Min. of Forestry, Min } \\
\text { of Public Works, } \\
\text { Min. of Agriculture, } \\
\text { Min of Environment }\end{array}$ \\
\hline Waste & 0.048 & 0.030 & $\begin{array}{l}\text { Sanitary landfill, } 3 \mathrm{R} \text { implementation, } \\
\text { integrated waste water management }\end{array}$ & $\begin{array}{l}\text { Min of Public Works, } \\
\text { Min of Environment }\end{array}$ \\
\hline Agriculture & 0.008 & 0.003 & $\begin{array}{l}\text { Introduction of low emission rice } \\
\text { variety, increase efficiency in use of } \\
\text { irrigated water, use of organic fertilizer }\end{array}$ & $\begin{array}{l}\text { Min. of Agriculture, } \\
\text { Min of Environment }\end{array}$ \\
\hline Industry & 0.001 & 0.004 & $\begin{array}{l}\text { Energy efficiency, renewable energy } \\
\text { use }\end{array}$ & Min. of Industry \\
\hline $\begin{array}{l}\text { Energy and } \\
\text { Transportation }\end{array}$ & 0.038 & 0.018 & $\begin{array}{l}\text { Increase use of biofuel, use of } \\
\text { increased efficiency standard } \\
\text { machines, increase quality of public } \\
\text { transportation, demand side } \\
\text { management, energy efficiency, } \\
\text { renewable energy development }\end{array}$ & $\begin{array}{l}\text { Min. of } \\
\text { Transportation, Min } \\
\text { of Public Works }\end{array}$ \\
\hline Total & 0.767 & 0.422 & & \\
\hline
\end{tabular}

Source: President Regulation No. 61/2011

Forestry and peat land was targeted will be the largest sector to reduce the emission by 0.672 Gigaton CO2e unilaterally and 0.367 Gigaton $\mathrm{CO} 2 \mathrm{e}$ with the international support. Additionally, energy and transportation sectors were targeted to reduce the emission by 0.038 Gigaton CO2e unilaterally and 0.18 
Gigaton CO2e with the international support. However, based on the total cost to reduce the emission, energy and transportation sectors have the highest cost with 94.7 trillion Rupiah for main activity and about 7 Trillions Rupiah for supporting activity and forestry and peat land sectors will only cost about 50 Trillions Rupiah for main and supporting activities by 2020 .

\section{Table 2: Mitigation Cost (in Billion Rupiahs)}

\begin{tabular}{l|c|c|}
\multicolumn{1}{|c|}{ Sector } & Main Activity* & Supporting Activity* \\
\hline \begin{tabular}{l|l} 
Forestry and Peat Land \\
Energy and \\
Transportation
\end{tabular} & $48.357,89$ & $\mathbf{2 . 2 8 6 , 1 0}$ \\
\hline Agriculture & $\mathbf{9 4 . 6 5 4 , 1 8}$ & $\mathbf{6 . 9 5 5 , 5 4}$ \\
\hline $\begin{array}{l}\text { Industry } \\
\text { Waste }\end{array}$ & $\mathbf{3 6 . 8 0 4 , 0 7}$ & $\mathbf{8 8 2 , 1 0}$ \\
\hline Other Supporting & $\mathbf{1 . 0 0 0 , 0 0}$ & $\mathbf{1 . 2 9 0 , 0 0}$ \\
\hline Activity & $\mathbf{4 4 . 7 0 9 , 3 3}$ & $\mathbf{4 . 9 4 9 , 5 2}$ \\
\hline TOTAL & - & $\mathbf{2 . 1 2 9 , 2 6}$ \\
\hline
\end{tabular}

Source: Bappenas (2012)

Carbon emitter trend: Nowadays, based on the data from Dewan Nasional Perubahan Iklim/ National Council on Climate Change (DNPI) the emission from energy and transportation sector is still lower compared with forestry and peat land sector which is less than 0.5 Gigaton CO2e in 2000 and 2005, but the trend of the emission from this sector will be increasing dramatically to more than 1 Gigaton CO2e in 2020. On the other hand, the emission from forestry and peat land sector tends to decline by 2020 .

\section{Figure 1: Carbon Emitter Trend (based on sector)}

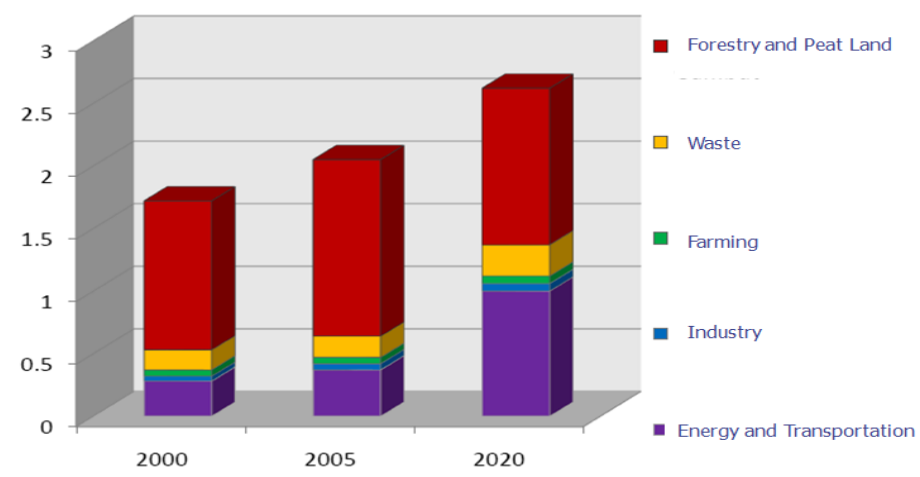

Source: DNPI (2012)

Thus, this study aims to depict the tax structure of hybrid car in Indonesia, to elaborate the potential incentive to hybrid car by imposing excise and how the excise can be potentially imposed to hybrid car. This study also found potential discrimination on the implementation of the excise on hybrid car. The discriminations are on the imported and domestic product and the different types of automotive (based on particular criteria such as: displacement and type of hybrid car).

\section{Methodology}

In order to meet the above objectives, this study employs desk study by tracking the existing regulation and its application in Indonesia. Therefore, focused group discussion and meeting with relevant 
stakeholders were conducted to have some perspectives from the expert on the existing situation and potential implementation of providing incentive to hybrid car in Indonesia through excise.

\section{Results}

Existing tax structure of hybrid car in Indonesia: In terms of trading activity, government provides several facilities to support the development of trading of automotives. The facility in trading, with regard to customs duty, is imposed based on the Minister of Finance No 213/PMK.011/2011 on the Determination of Classification System on Goods and Customs Duty Tariff on the Imported Goods. On the other hand, the Minister of Finance also stipulated regulation which supports the competitiveness of the industry of automotive and to increase the use of local content for automotive. The regulation introduced and allows the import of Incompletely Knock Down (IKD) and the components. That regulation is the Minister of Finance Decree No. 88/PMK.011/2010 on the Third Amendment of the Minister of Finance Decree No. 110/PMK.010/2006 on the Determination of Classification System on Goods and Customs Duty Tariff on the Imported Goods.

Table 3: Determination of Classification System on Goods and Customs Duty Tariff on the Imported Goods of Automotives

\begin{tabular}{|c|c|c|c|}
\hline No & Post/Sub Post & Description & Duty \\
\hline & 98.01 & Incompletely knocked down motor vehicles & \\
\hline & 9801.1 & - Motor vehicles for the transport of persons of heading & \\
\hline 1 & 9801.10 .10 .00 & - - Sedan with cylinder capacity not exceeding $1,500 \mathrm{cc}$ & 7.5 percent \\
\hline 2 & 9801.10 .20 .00 & - - Motor vehicles other than sedan with two wheel drive & 7.5 percent \\
\hline 3 & 9801.10 .30 .00 & - - Motor vehicles other than sedan with four wheel drive & 7.5 percent \\
\hline & 9801.20 & - Motor vehicles for the transport of goods of heading 87.04: & \\
\hline 4 & 9801.20 .10 .00 & - - Of a gross vehicle weight not exceeding 5 ton & 7.5 percent \\
\hline 5 & 9801.20 .20 .00 & - - Of a gross vehicle weight exceeding 5 ton but not & 0 percent \\
\hline 6 & 9801.20 .30 .00 & - - Of a gross vehicle weight exceeding 24 ton & 0 percent \\
\hline & 9801.30 & - Motor vehicles for the transport of more than 10 persons of & \\
\hline 7 & 9801.30 .10 .00 & - - Of a gross vehicle weight not exceeding 5 ton & 7.5 percent \\
\hline 8 & 9801.30 .20 .00 & - - Of a gross vehicle weight exceeding 5 ton but not & 0 percent \\
\hline 9 & 9801.30 .30 .00 & - - Of a gross vehicle weight exceeding 24 ton & 0 percent \\
\hline & 98.02 & Components of incompletely knocked down motor vehicle. & \\
\hline 10 & 9802.10 .00 .00 & - Rotary internal combustion piston engine or reciprocating & 2.5 percent \\
\hline 11 & 9802.20 .00 .00 & - Gear boxes & 2.5 percent \\
\hline 12 & 9802.30 .00 .00 & - Drive-axles & 2.5 percent \\
\hline 13 & 9803.00 .00 .00 & Blank for motor vehicles component, made from base metal. & 5 percent \\
\hline
\end{tabular}

Instead of just Customs Duty, automotive also levied by Luxury Goods Tax (LGT). Details of the two taxes on automotive are summarized as follows: 
Table 4: Levies of Automotives based on the Displacement

\begin{tabular}{|c|c|c|c|c|c|c|c|c|c|c|}
\hline \multirow{3}{*}{ Type } & \multirow{3}{*}{ Displacement } & \multicolumn{6}{|c|}{ Duty Tariff (\%) } & & & \multirow{3}{*}{$\begin{array}{l}\text { LGT } \\
\text { (\%) }\end{array}$} \\
\hline & & \multicolumn{2}{|l|}{ CBU } & \multicolumn{2}{|l|}{ CKD } & \multicolumn{2}{|l|}{ IKD } & \multicolumn{2}{|c|}{ Component } & \\
\hline & & 2010 & 2011 & 2010 & 2011 & 2010 & 2011 & 2010 & 2011 & \\
\hline \multirow[t]{3}{*}{ SEDAN } & $\mathrm{CC}<1.5 \mathrm{lt}$ & 50 & 40 & 15 & 10 & 7.5 & 7.5 & $0-15$ & $0-10$ & 30 \\
\hline & $\begin{array}{l}1.5 \mathrm{lt}<\mathrm{CC}<3.0 \\
\text { lt (P) / } 2.5 \mathrm{lt} \\
\text { (D) }\end{array}$ & 50 & 40 & 15 & 10 & - & - & $0-15$ & $0-10$ & 40 \\
\hline & $\begin{array}{l}\mathrm{CC}>3.0 \text { lt }(\mathrm{P}) / \\
2.5 \text { (D) }\end{array}$ & 50 & 40 & 15 & 10 & - & - & $0-15$ & $0-10$ & 75 \\
\hline \multirow{4}{*}{$\begin{array}{l}\text { MPV } \\
4 \times 2\end{array}$} & $\mathrm{CC}<1.5 \mathrm{lt}$ & 45 & 40 & 15 & 10 & 7.5 & 7.5 & $0-15$ & $0-10$ & 10 \\
\hline & $\begin{array}{l}1.5 \text { lt }<\text { CC }<2.5 \\
\text { lt }\end{array}$ & 45 & 40 & 15 & 10 & 7.5 & 7.5 & $0-15$ & $0-10$ & 20 \\
\hline & $\begin{array}{l}2.5 \mathrm{lt}<\mathrm{CC}<3.0 \\
\operatorname{lt}(\mathrm{P})\end{array}$ & 45 & 40 & 15 & 10 & 7.5 & 7.5 & $0-15$ & $0-10$ & 40 \\
\hline & $\begin{array}{l}\mathrm{CC}>3.0 \mathrm{lt}(\mathrm{P}) / \\
2.5(\mathrm{D})\end{array}$ & 45 & 40 & 15 & 10 & 7.5 & 7.5 & $0-15$ & $0-10$ & 75 \\
\hline \multirow[t]{3}{*}{ SUV 4X4 } & $\mathrm{CC}<1.5 \mathrm{lt}$ & 45 & 40 & 15 & 10 & 7.5 & 7.5 & $0-15$ & $0-10$ & 30 \\
\hline & $\begin{array}{l}1.5 \mathrm{lt}<\mathrm{CC}<3.0 \\
\mathrm{lt}(\mathrm{P}) / 2.5(\mathrm{D})\end{array}$ & 45 & 40 & 15 & 10 & - & - & $0-15$ & $0-10$ & 40 \\
\hline & $\begin{array}{l}\mathrm{CC}>3.0 \mathrm{lt}(\mathrm{P}) / \\
2.5(\mathrm{D})\end{array}$ & 45 & 40 & 15 & 10 & - & - & $0-15$ & $0-10$ & 75 \\
\hline \multirow[t]{3}{*}{ BUS } & $\begin{array}{l}\text { GVW }<5 \text { ton } \\
(\mathrm{P} / \mathrm{D})\end{array}$ & 40 & 40 & 15 & 10 & 7.5 & 7.5 & $0-15$ & $0-10$ & 10 \\
\hline & $\begin{array}{l}5 \text { ton }<\mathrm{GVW} \leq \\
24 \text { ton }(\mathrm{P} / \mathrm{D})\end{array}$ & 40 & 40 & 15 & 10 & 0 & 0 & $0-15$ & $0-10$ & 10 \\
\hline & $\begin{array}{l}\text { GVW > } 24 \text { ton } \\
(\mathrm{P} / \mathrm{D})\end{array}$ & 10 & 10 & 5 & 5 & 0 & 0 & $0-15$ & $0-10$ & 10 \\
\hline $\begin{array}{l}\text { (TRUCK } \\
\text { /PICK }\end{array}$ & $\begin{array}{l}\text { GVW }<5 \text { ton } \\
(\mathrm{P} / \mathrm{D})\end{array}$ & 45 & 40 & 15 & 10 & 7.5 & 7.5 & $0-15$ & $0-10$ & 0 \\
\hline \multirow[t]{2}{*}{ UP) } & $\begin{array}{l}\text { GVW } 5-24 \text { ton } \\
\text { (P/D) }\end{array}$ & 40 & 40 & 15 & 10 & 0 & 0 & $0-15$ & $0-10$ & 0 \\
\hline & $\begin{array}{l}\text { GVW > } 24 \text { ton } \\
(\mathrm{P} / \mathrm{D})\end{array}$ & 10 & 10 & 5 & 5 & 0 & 0 & $0-15$ & $0-10$ & 0 \\
\hline $\begin{array}{l}\text { Double } \\
\text { Cabin } \\
4 \times 2 / 4 \times 4\end{array}$ & $\begin{array}{l}\text { GVW }<5 \text { ton } \\
(\mathrm{P} / \mathrm{D})\end{array}$ & 45 & 40 & 15 & 10 & 7.5 & 7.5 & $0-15$ & $0-10$ & 20 \\
\hline
\end{tabular}

Source: MoF, Minister of Finance Decree No 213/PMK.011/2011

Tax Policy on Hybrid Car in Thailand: In Thailand, both green classification and green tax are applied. This policy seen as one of the factors that drives succesfulness of the development of industry and trade in environmentally friendly vehicles in Thailand. The structure of tax in Thailand formulated based on the categorization of the Excise Tax. The purpose of this application is to encourage the use of environmentally friendly vehicles (energy efficient car). On the other hand, different policy is implemented in Indonesia. Tax structure in Indonesia is imposed based on vehicle type and size of displacement and does not distinct either the environmental friendly car or not. In Thailand, the tendency of the tax tariff of environmental friendly vehicles lower than vehicles using gasoline fuel. Imposition of taxes on hybrid vehicles only taxed at 10 percent, while Van vehicles which are fueled gasoline (petrol) taxed up to 30 percent. While in Indonesia, the car imposed of maximum $75 \%$ for both the conventional one (gasoline) and environmentally friendly car. The application of this policy in Indonesia will provide less incentive to the car producers to produce and sell an environmental friendly car. 
Table 5: Comparison of tax structure on Vehicles in Thailand and Indonesia

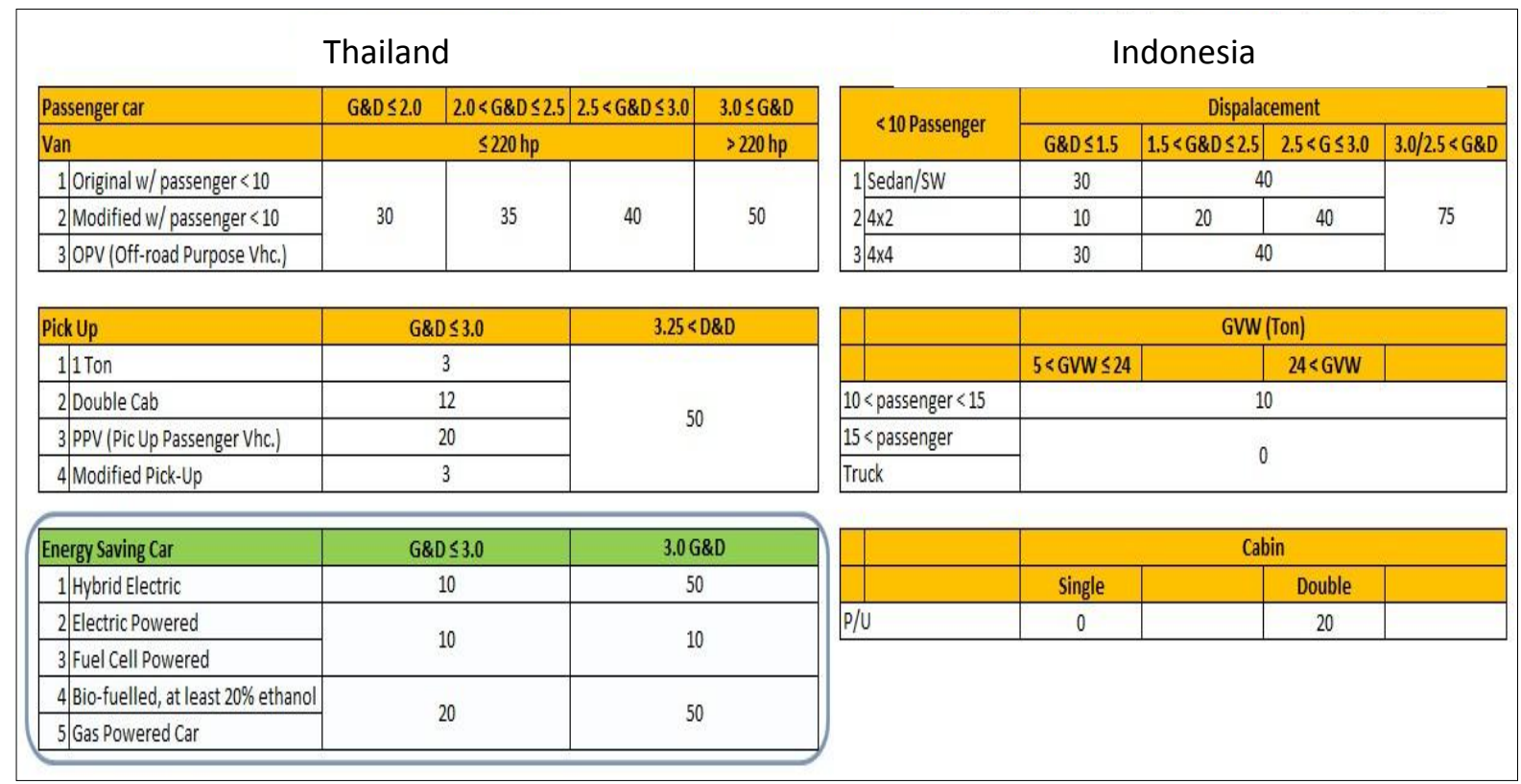

Source: Gaikindo (2012)

\section{Excise vs Luxury Goods Tax}

Pigouvian Tax: There are several government interventions to address the issue of externalities, one of which is via imposing tax, which is called as Pigouvian Tax. According to Rosen and Gayer (2008), Pigouvian tax is "a tax levied on each unit of a polluter's output in an amount just equal to the marginal it inflicts at the efficient level of output."

\section{Figure 2: Market Equilibirum With and Without Fines (Tax)}

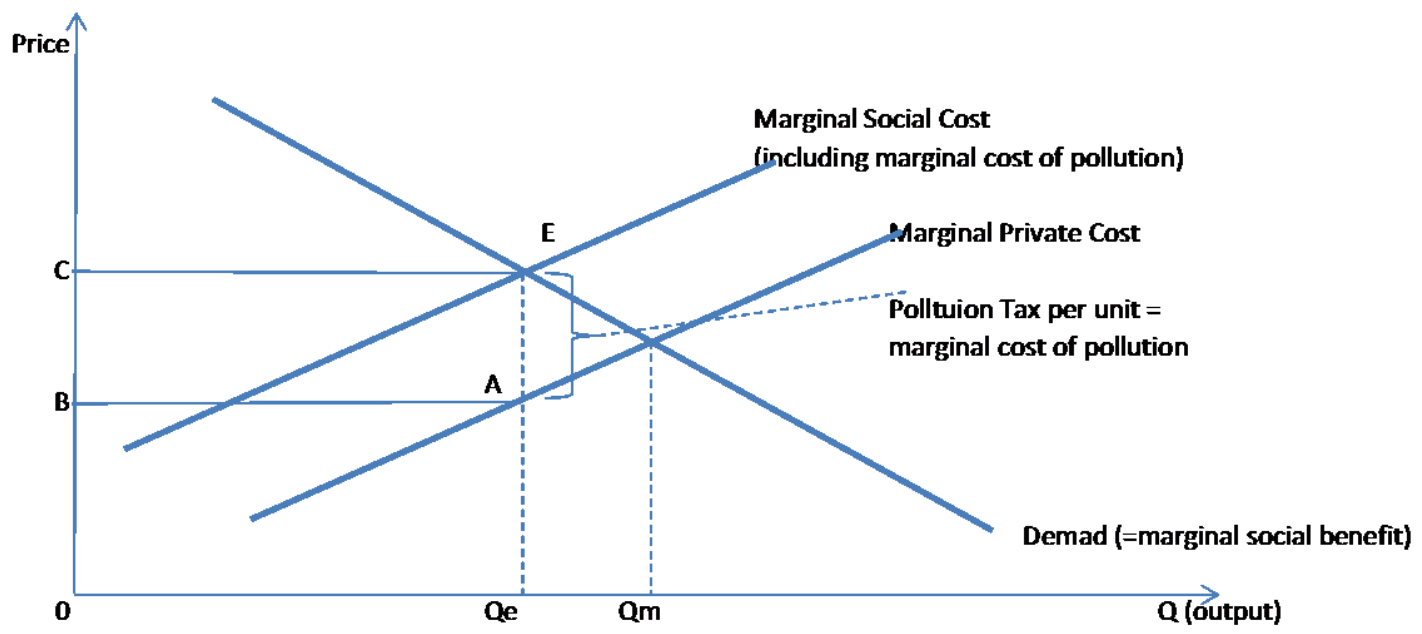

Source: Stiglitz (1999)

According to the above figure, Stiglitz (1999) explained that by imposing Pigouvian tax to the polluting things, will ensure the polluting firm to undertake the pollution abatement in the most efficient way.

Nature of excise: The definition of excise as mentioned in Law No 39 yearly 2007 on the amendment of Law No 11 yearly 1995 on excise is the state levy which is imposed to the particular goods which has nature and characteristic, i.e.: its consumption need to control; its circulation need to supervise; its use ensuing a negative impact to community or environment; and its use needs to impose a state levy in purpose of justice and balance. Excise has a special characteristic which is different to another kind of 
taxes. And even though categorized as one of the indirect tax, excise still has its specialties. According Cnossen (2005) those specialties are:

a) Selected coverage: The selected goods which can be imposed by excise are the goods which are mentioned by the excise law particularly. This is the most problematic in Indonesia case since in the diversification program of object of excise. In the Law on Excise, the selected goods which are imposed by excise are only for 3 (three) kinds of goods only, even though it is mentioned that in the initial philosophy has been acknowledged on the possibility of diversification of the excised object.

b) Discrimination in its purposes: Excise is one of the most important indirect tax in several countries mostly in developing countries in terms of its total revenue. Yet, the imposing excise has also other purposes, such as:

- to control the consumption of particular goods which is beyond the community norms and healthcare, e.g.: cigarette and liquor;

- to be imposed on luxury goods by concerning its taxpaying capacity;

- to be imposed on vehicle as burden of the use of the road;

- to maintain the use of natural sources efficiently;

- excise on raw material to reduce the waste;

- to provide employment by imposing high excise to the capital goods which is potentially replacing the human labour;

- to finance research and trade promotion.

c) Quantitative measurement in the investigation: In the imposing excise, the officer statutorily can conduct a physical supervision to ensure the compliance level of the subjects of the excised goods in this term is the private sectors. The main philosophy of imposing excise according to OECD is to increase the revenue, to influence the consumer behaviour and utilize the market power to change the consumption pattern. According to those philosophy, most of OECD countries impose the excised goods on three items i.e. liquor, mineral oil and tobacco. In Indonesia, the excised goods consist of three goods which are liquor, ethyl alcohol and tobacco products or cigarette.

Nature of LGT: Based on Law No. 18 year 2000 on amendment Law No. 8 year 1983 on Value Added Tax (VAT) and Luxury Goods Tax, government imposes VAT as well as Luxury Goods Tax. The above mentioned Law also describes the criteria of luxury goods, which are:

- Not a staple goods,

- Not consumed by everyone (but just particular person or people).

- Generally consumed by high income consumer.

- The goods show a lifestyle or the status of the consumer.

- Those goods have negative impact to the health, moral and potentially will induce misconduct of the community e.g. alcoholic beverages.

There are several criteria of LGT objects which are similar with the excise, that are: the negative impact of the use of the goods, its consumption needs to control, and to be imposed on luxury goods. Therefore there is potential way to shift the LGT objects to Excise objects due to its imposing purposes are similar. Today based on the Decree of Ministry of Finance No 591/KMK.04/1986 there are two groups of LGT objects, which are:

Table 6: LGT Objects

\begin{tabular}{ll}
\hline Group I (LGT 10\%) & Group II (LGT 20\%) \\
\hline Non alcoholic soft drink & Liquor \\
Motor cycle & Racing vehicle \\
Luxury electronics means & Vehicles; type sedan, jeep and racing \\
Photography tools & Excursion boat \\
Luxury sport means &
\end{tabular}

Source: MOF, Minister of Finance Decree No. 591/KMK.04/1986

Nature of Hybrid Car and other automotives 
1) Less polluted and less fuel consumed car: For the sake of providing fiscal incentive for green product, particularly hybrid car, several technical criteria are required. It is expected that the technical criteria will lead to the right object which will be granted with fiscal incentive. There are several types of environmental friendly automotives such as hybrid car, electric car, solar car as well as hydrogen car. Yet, currently in the world and Indonesia particularly, the most well developed and used is the hybrid. Several technical aspect of hybrid car which can be used such as (Gaikindo, 2012):
a) Technology
: Combination of combustion and electric
b) Type of vehicle
: All types (CV dan PC Based)
c) Cylinder Capacity
: All types
d) Fuel Consumption
: $\geq 35 \mathrm{Km} /$ Liter
e) Emission
$:<75 \mathrm{Gram} / \mathrm{Km}$

Although all types of vehicle are able to be developed as hybrid, yet only several types that are very well developed nowadays, i.e. sedan and non sedan with cylinder capacity more than $1500 \mathrm{cc}$.

2) Price disparity between hybrid and conventional car: Constraints in developing hybrid vehicles in Indonesia are as follows (Gaikindo, 2012):

1. Price Hybrid Vehicle on average 40 percent more expensive than conventional cars and sales are relatively small ( $\leq 10$ units / month);

2. Technology masterships in Indonesia is relatively low and has not been in produced in Indonesia because it has not been feasible ( $\geq 300$ units / month);

3. Lack of infrastructure support, and

4. Level of understanding of society is still relatively limited.

One of the constraints on the developing hybrid car in Indonesia is the price of hybrid car relatively higher for about $40 \%$ compared with conventional car. This calls for an incentive in order to the consumer eager to have hybrid car.

1. Discrimination treatment on excise policy: In fact, by practice and regulation in Indonesia, the excise policy is acknowledging the discrimination. The discriminations are purposed to meet several objectives like: to protect the small company from big company, handmade company from machine made company and social and health aspects of the consumption.

Table 7: Discrimination on imposing excise

\begin{tabular}{lll}
\hline Type of excise & Discrimination & Objectives \\
\hline Excise on cigarette: & $\begin{array}{l}\text { companies are grouped based on } \\
\text { the level of the production each }\end{array}$ & big company \\
& $\begin{array}{l}\text { year } \\
\text { handmade cigarette and machine } \\
\text { made cigarette }\end{array}$ & $\begin{array}{l}\text { to protect labor intensive } \\
\text { industry }\end{array}$ \\
& $\begin{array}{l}\text { type of cigarette/ tobacco } \\
\text { content health and social aspect } \\
\text { imported and domestic product } \\
\text { high alcoholic content }\end{array}$ & $\begin{array}{l}\text { to protect the domestic industry } \\
\text { health and social aspect }\end{array}$ \\
\hline
\end{tabular}

Source: Author's resume (2013)

2. The potential incentive: The incentive should be provided by government with the consideration that hybrid car will need support on its development in Indonesia. The incentive can be given with purposes as follows:

- To minimize the price disparity with the conventional car: In the short run, the government may provide incentive in the trading sector. The objective of this policy is to reduce the price disparity between hybrid and conventional car. This is under consideration that the industry has not been ready.

- To enhance the domestic industry: In the medium and long term, the development of hybrid car can be implemented on the industry level. The objective is to support the development of the domestic industry of hybrid car, with the priority to utilize domestic components.

How excise can be used as the incentive: Excise can be imposed with different tariff for several purposes and treatment. This is under consideration that the objective of excise can be used for internalizing the externalities which in the context of hybrid car is the level of pollution which is lower than the conventional one. 
- Discrimination tariff for hybrid car: The discrimination can be given to the hybrid car with lower excise tariff due to the social and health aspect. As the hybrid car is less polluted and less fuel subsidized, then the lower excise tariff will attract people to buy hybrid car rather conventional car. The optimal revenue will be gathered by government since there are aspects of compliance must be obeyed by the tax payer such as reporting, physical checking and auditing.

- Discrimination tariff for the lower cylinder capacity among hybrid car: The higher cylinder capacity tends to consume fuel more and pollute more compared with the lower one. Thus, the discrimination may be applied for the lower cylinder capacity of hybrid car.

- Discrimination tariff for domestic hybrid car: Since the development of this type of car is still low, then the incentive should be provided. By discriminating the domestic hybrid car product, the investment will be coming. The upstream industry will enjoy the demand from the downstream as the finished goods is enjoying the facility.

In above all of them, the specific criteria on hybrid car which is facilitated should be clear. Because if the facility cannot recognize the exact object, thus the facility will not answer the needs of incentivizing the hybrid car. This calls for discussions and insights from relevant stakeholders such as Ministry of Industry, Ministry of Trade, Automotive Association and Ministry of Energy and Natural Resources.

\section{Conclusion}

Arguing that the government needs to provide incentive to the hybrid car and its development, thus excise can be one of the potential way to provide that. This is concluded by taking into consideration its merit including selected coverage, discrimination in its purposes and has quantitative measurement in the investigation. Additionally, government may opt to switch the LGT to excise to avoid over taxation. Finally, to proivde the incentives, an excise can be imposed under several discrimination on its imposition under the basis of particular purposes such as the level of consumption of fuel/ subsidy from government, pollution and emission curbed and price disparity.

\section{References}

Bappenas (Badan Perencanaan Pembangunan Nasional - State Ministry of National Development Planning. (2012). Rencana Aksi Nasional: Tantangan dan Peluang RAN-GRK (National Action Plan: Opportunity and Threat. FGD Opportunity to Finance and Provide Fiscal Incentive to support RAN GRK, Bogor, 3 May 2012.

Cnossen, S. (2005). Economics and Politics of Excise Taxation. Theory and Practice of Excise Taxation. Oxford, Oxford University Press: 1-19.

Dewan Nasional Perubahan Iklim. (2012). Energi dan Perubahan Iklim (Energy and Climate Change). FGD Opportunity to Finance and Provide Fiscal Incentive to support RAN GRK, Bogor, 3 May 2012.

Gaikindo (Gabungan Industri Automotif Indonesia - The Association of Indonesia Automotive Industries Indonesia International Motor). (2012). Pengembangan industri kendaraan bermotor roda-4 ramah lingkungan (Development of Automotive Industry on Green Vehicle), FGD Tax Incentives for Green Product, Jakarta, 20 June 2012.

Government of Indonesia. (2007). Undang-undang No 39 tahun 2007 tentang Perubahan Undang-undang No 8 tahun 1983 tentang Pajak Pertambahan Nilai dan Pajak Penjualan Barang Mewah (Law No 39 year 2007 on Amandement of Law No 8 year 1983 on Value Added Tax and Luxury Goods Tax). Jakarta: Government of Indonesia.

Government of Indonesia. (2000). Undang-undang No 18 tahun 2000 tentang Perubahan Undang-undang No 11 tahun 1995 tentang Cukai (Law No 18 year 2000 on Amandement of Law No11 year 1995 on Excise). Jakarta: Government of Indonesia.

Ministry of Finance. (2008). Peraturan Menteri Keuangan Nomor 203/PMK.011/2008 tentang Tarif Cukai Hasil Tembakau (Decree No 203/PMK.011/2008 on Excise Tariff of Tobacco Products). Jakarta: Ministry of Finance.

Ministry of Finance. (2010). Peraturan Menteri Keuangan Nomor 62/PMK.011/2010 tentang Tarif Cukai Etil Alkohol, Minuman yang Mengandung Etil Alkohol, dan Konsentrat yang Mengandung Etil Alkohol (Decree No 62/PMK.011/2010 on Excise Tariff of Etyl Alcohol, Alcoholic Beverages, and Concentrate contained Etyl Alcohol). Jakarta: Kementerian Keuangan.

Ministry of Finance. (2011). Peraturan Menteri Keuangan Nomor 213/PMK.011/2011 tentang Penetapan Sistem Klasifikasi atas Barang dan Tarif Bea Masuk Barang Impor (Decree No 
213/PMK.011/2011 on Determination of Classification System on Goods and Customs Duty Tariff). Jakarta: Ministry of Finance.

Ministry of Environment. (2010). Peraturan Menteri Lingkungan Hidup Nomor 04 Tahun 2009 tentang Ambang Batas Emisi Gas Buang Kendaraan Bermotor Tipe Baru (Decree No 04 year 2009 on Maximum Exhaust Emissions Limits for New Type Motor Vehicle), Jakarta: Ministry of Environment.

Ministry of Environment. (2010). Peraturan Menteri Lingkungan Hidup Nomor 07 Tahun 2009 tentang Ambang Batas Kebisingan Kendaraan Bermotor Tipe Baru (Decree No 07 year 2009 on Maximum Noise Limits for New Type Motor Vehicle), Jakarta: Ministry of Environment.

Lembaga Ilmu Pengetahuan Indonesia (Indonesia Institue of Science). (2010). Kebijakan Nasional Mobil Listrik (National Policy on Electricity Car), Bandung: LIPI Press

President Regulation No 61 yearly 2011 on National Action Plan to Mitigate Green House Gas Emission. Rosen, H. S. \& Gayer, T. (2008). Public Finance, McGraw-Hill, Boston, 8th edition.

Stiglitz, J. E. (1999). Economics of the Public Sector, 3rd Edition, W.W. Norton \& Company. 